\title{
Welfare Reform and Family Expenditures: How Are Single Mothers Adapting to the New Welfare and Work Regime?
}

\author{
Neeraj Kaushal \\ Columbia University \\ Qin Gao \\ Fordham University \\ Jane Waldfogel \\ Columbia University
}

\begin{abstract}
This work studies the association between welfare reform, broadly defined to include an array of social policy changes affecting low-income families in the 1990s, and expenditure patterns of poor single-mother families. The findings suggest that welfare reform is not associated with any statistically significant change in total expenditures in families headed by low-educated single mothers. However, patterns of expenditure changed. The reform policy is associated with an increase in spending on transportation and food away from home, as well as on adult clothing and footwear. In contrast, it is not related to changes in expenditures on child care or learning and enrichment activities. The pattern of results suggests that welfare reform has shifted family expenditures toward items that facilitate work outside the home but, at least so far, does not allow low-income families to catch up with more advantaged families in expenditures on learning and enrichment.
\end{abstract}

A decade-long policy to "end welfare as we know it" (Clinton 1992) has dramatically altered the life circumstances and opportunities of families headed by single mothers in the United States. Approximately 69 percent of single mothers were employed in 2005, up from 61 percent a decade earlier. Further, after falling by half within the first 5 years of the implementation of the 1996 welfare law (Personal Responsibility

Social Service Review (September 2007).

(C) 2007 by The University of Chicago. All rights reserved.

0037-7961/2007/8103-0001\$10.00 
and Work Opportunity Reconciliation Act [PRWORA]; U.S. Public Law 104-193), the number on welfare continued to decline even during the 2001 recession (Parrott and Sherman 2006; U.S. House of Representatives 2006). A rich body of research documents the effects of welfare reform on the employment and income of low-educated single mothers (Blank 2002; Grogger, Karoly, and Klerman 2002). This article provides evidence on how welfare reform affects their patterns of expenditure, another important outcome that is drawing increasing attention from poverty researchers.

In their extensive research using expenditure data, Bruce Meyer and James Sullivan $(2004,2006)$ find that the incomes of the poorest (bottom decile) single-mother families fell noticeably after welfare reform, but total expenditures increased. It is not clear, however, whether the increase in expenditures is due to changes in social policy or to economic factors. Previous research concludes that economic factors had a larger effect on welfare caseloads than social policy changes did; only one-tenth to one-third of the decline in welfare caseloads can be attributed to welfare reform (see Council of Economic Advisors 1999, Figlio and Ziliak 1999; Ziliak et al. 2000; Blank 2002). In any case, it is important to separate the effects of policy from economic factors. This work uses a difference-in-difference-in-difference (DDD) research design, described in detail below, to isolate the influence of changes in social policy on expenditure patterns of low-income families and to differentiate that influence from the effects of other time-varying factors.

The second contribution of the current work is to analyze trends in expenditures on specific items, such as those related to work or child development and learning, so as to examine how single-mother families are adapting to their new life circumstances. Again, the focus is on whether trends in expenditures are caused by social policy or economic factors. ${ }^{1}$ For example, if circumstances changed as a result of welfare reform, families may be required to spend more on such work-related items as transportation, food away from home, and adult clothing. Realizing the significance of education in the labor market, families may decide to spend more on development or learning activities. Working families may also purchase more child care (which may or may not benefit children, depending on such factors as the age of the child and the quality of the care).

In general, findings from the current research contrast with those of Meyer and Sullivan $(2004,1405)$, who conclude that the post-welfarereform "increase in consumption does not appear to be driven by work expenses." This contrast may be due to the fact that their analysis does not include transportation and adult clothing in the definition of work expenses and that the analysis does not adjust for time-varying factors contemporaneous with welfare reform. 


\section{Policy Background and Previous Research}

A spate of policy changes in the 1990s shifted the focus of U.S. welfare policy from providing cash benefits for low-income single mothers to providing work incentives and a range of supports for the working poor. The 1996 federal law and related state initiatives discouraged welfare dependence by eliminating the entitlement to cash assistance, by creating mandatory work requirements, and by imposing time limits on welfare receipt. The changes were accompanied by expansions in such work support programs for low-income families as federal and state Earned Income Tax Credits, child-care subsidies, child tax credits, Medicaid, and child health insurance programs. These expansions radically altered the focus of public assistance available to low-income singlemother families. The changes are well documented elsewhere (see Blank 2002; Grogger et al. 2002).

These policy changes were implemented between 1992 and 2000, when the U.S. economy experienced an impressive growth that generated over 20 million jobs (Blank 2000). Perhaps partly due to changes in incentives brought about by tax and transfer programs, and partly on account of economic growth, the employment rate of low-educated single mothers increased from 62 percent in 1995 to 73 percent in 2000. That rate declined in the recent recession to 69 percent in 2005 (Parrott and Sherman 2006). But it is not easy to determine what proportion of the increase in employment (or incomes) is due to policy and what proportion is due to economic factors (Blank 2002). Moreover, multiple policy changes occurred during a short time period, and it is thus difficult to attribute changes in income or other aspects of families' circumstances to a single aspect of welfare reform or to work assistance programs.

According to the U.S. Census Bureau (n.d.), the poverty rate among children in single-mother families declined from 54 percent in 1993 to 43 percent in 2005. This decline is due in part to the economic boom of the 1990s and in part to such other factors as changes in tax and transfer programs. Maria Cancian and associates (1999) find that, after adjusting for inflation, both earnings and family incomes of welfare leavers increased over time (see also Haskins 2001). The scenario is less promising for the very poor. Ron Haskins $(2001,105)$ concludes, "There is a small to moderate-sized group of mother-headed families that are worse off than they were before welfare reform." Wendell Primus and colleagues (1999) find that the 1996 welfare reform caused a decline in disposable income for the bottom decile of the population (see also Meyer and Sullivan 2005). The picture is mixed as one looks at other aspects of family circumstances (Winship and Jencks 2002; Bitler, Gelbach, and Hoynes 2005; Kaushal and Kaestner 2005).

Expenditures, understudied until recently, are an important indicator 
of families' material well-being. Several researchers argued recently that examining expenditure yields a more accurate measure of poverty than is obtained by focusing on income (Meyer and Sullivan 2003, 2004, 2006; Rector 2004; see also Haskins 2001). Further, Meyer and Sullivan's (2004) study finds that total expenditures in single-mother families increased after welfare reform. The researchers use the expenditure distribution to select single mothers and low-educated single mothers at the fifteenth and twenty-fifth deciles of the distribution, finding that the increase in expenditure is particularly noticeable for these groups. They attribute the increase to welfare and tax reforms during the 1990s. This inference is based on the assumption that expenditures of low-income families were not affected by factors contemporaneous with welfare reform. The current research drops this assumption, estimating the association between welfare reform and expenditures by adopting a comparison group research methodology that controls for other time-varying factors in a parsimonious manner. Further, the current sampling frame may be advantageous. Meyer and Sullivan's (2004) use of expenditure data to stratify samples is potentially problematic. If welfare reform affected expenditures, membership of individuals in various deciles would change, resulting in estimates that suffer from sampling bias.

As is the case in any study on expenditures, the current work is limited by the lack of data on the quality of the items that families purchase or own. The study does not take into account data on other aspects of family circumstances or child well-being. For instance, tax incentives and welfare reforms that increase the employment of mothers may affect the time mothers spend with children, and resulting changes may adversely affect the well-being of children. If mothers gain employment, it is also possible that associated improvements in maternal health and family routines will bring gains in the well-being of children (Duncan and Chase-Lansdale 2004; Waldfogel 2006). Similarly, employment may entail more or less physical exertion than that required by household work, and the psychological stress of household work may differ from that of paid work. Mothers' self-esteem may be high when they are employed and low when they are on welfare (Kane 1987). The current analysis does not factor in such aspects of well-being as mothers' mental and physical health or the quality of the time they spend with children.

\section{Data}

This work relies on microlevel data from the U.S. Bureau of Labor Statistics' Consumer Expenditure Surveys (CESs). The data cover 2 periods. Data from 1990 to 1995 cover the prereform period, and data on the postreform period are from 1998 to 2003. All states implemented PRWORA in 1996 and 1997. Because data from this period cannot be categorized as pre- or postreform, they are excluded from analyses. The 
CESs consist of two different components: a quarterly interview survey (IS) and a weekly diary survey. The current analyses are based on the IS, which provides detailed information on expenditures incurred by a sample of consumer units. In this article, a consumer unit is defined as all members of a housing unit who are related by blood, marriage, adoption, or some other legal arrangement; two or more persons who live together and use their incomes to make joint expenditures; or a single person who is living with others but is financially independent (U.S. Bureau of Labor Statistics 2005). The IS sample is a rotated panel in which approximately 7,500 units are interviewed every 3 months for 5 consecutive quarters. After that time, these families are replaced by new units. ${ }^{2}$ Thus, by design, 20 percent of the sample is replaced every quarter. A contact interview is conducted in the first quarter. In the second to fifth quarters, families are asked about their expenditures over the 3 months that precede the interview. Because the IS data are based on respondents' recollection of expenditures in the 3 preceding months, the data suffer from response recall errors (Battistin 2003). ${ }^{3}$

Analyses are restricted to families with children and a mother who is between the ages of 18 and 54. Education and marital status are used to select groups most and least likely to be affected by welfare reform. Since the CES provides data at the family level and not at the subfamily level, the research cannot identify single mothers who reside in a household with parents or other family members. If welfare reform compels an increased number of single mothers to live with their parents, the analyses are biased. ${ }^{4}$ Meyer and Sullivan (2003) use the U.S. Census Bureau's Current Population Surveys to compute the ratio of singlemother subfamilies to all single mothers. They find that the ratio was around 0.2 throughout the 1990s. This suggests that, in the CES data, there is only a modest risk that bias may result from changes in the proportion of single-mother subfamilies.

The CES provides detailed information on each family unit. This information includes respondent's (and spouse's) age, education level (and spouse's education level), marital status, race and ethnicity (and that of the spouse), region of residence, family size, number of children, and number of elderly persons (age 65 or above) in the family. This information is used to construct various demographic categories and control variables.

Quarterly expenditures are classified into 10 major categories: housing and utility; food; alcohol and tobacco; clothing, footwear, and accessories (hereafter, clothing and footwear); transportation; health; leisure; personal care; education (including reading); and miscellaneous (for descriptions, see appendix table A1). The analysis considers whether welfare reform affects expenditures on each category. The CES also provides data concerning expenditures on more narrowly defined items that can be assigned to expenses associated with work, learning, or 
development. The data are thus also used to define and analyze the following detailed expenditure categories: food away from home, adult's clothing and footwear, child care and babysitting, and learning and enrichment. ${ }^{5}$ As appendix table A2 shows, learning and enrichment expenditures include spending on books, magazines, newspapers, tuition (elementary, high school, and college), schoolbooks, school supplies, school equipment, computers, calculators, typewriters, toys, games, sports, and enrichment activities. For comparison, this study also considers changes in expenditures on food at home as well as on children's clothing and footwear.

The study considers trends in ownership of several consumer durables. These trends may reveal whether welfare reform induced families to invest in durables to save time in household work (e.g., microwave ovens, washers and dryers, and dishwashers); to better connect with employers, family, or friends (e.g., phone and car); or to enhance learning (e.g., computer and videocassette recorder [VCR]). Data from the CESs provide information on ownership of all of these items except phones. Information on whether a family spent any money on phone services in the quarter prior to being surveyed is used as a proxy for phone ownership.

To take account of differences in family size and composition, expenditures in the 10 major categories are adjusted for family size. Adjustments are made using an equivalence scale that assigns a weight of 0.67 to the first adult, 0.33 to all other persons in the family over age 17 , and 0.2 to children under age 18 . This equivalence is similar to that being used by the OECD (Organization for Economic Cooperation and Development; OECD n.d.). The OECD scale assigns 0.33 to all other persons in the household age 14 or over and 0.2 to children under 14 . Since all persons under age 18 are considered children in the United States, the OECD scale is modified to meet U.S. norms. Specific items (i.e., adult clothing and footwear, children's clothing and footwear, and child care and babysitting) are adjusted by the number of adults or children in the family who are likely to use these goods and services. This study uses the Personal Consumption Expenditures index of the U.S. Bureau of Economic Analysis (n.d.), expressing expenditures in January 2003 dollars.

A major limitation of the CES data is that they provide state identifiers for only some members in the sample. For instance, in 2003, CESs did not provide state codes for 15 states and suppressed state codes for some respondents from 17 other states. Therefore, as in studies by Meyer and Sullivan $(2004,2006)$, the current work cannot control for time-varying state effects. In general, DDD methodology, described in detail below, is used to control for any time-varying state effects. 


\section{Methodology}

One simple way to examine welfare-reform-related shifts in expenditure patterns of low-educated single mothers is to compute the pre- to postwelfare-reform changes in levels of expenditures by these families. Analyses follow the methodology used by Paul Gregg, Jane Waldfogel, and Elizabeth Washbrook (2006) in a study of family expenditures in the United Kingdom. The change is estimated using levels or percentage methods as specified below:

$$
\begin{gathered}
\text { levels method: } \lambda_{l s}=\overline{E_{l s}^{\text {post }}}-\overline{E_{l s}^{\text {pre }}}, \\
\text { percentage method: } \lambda_{l s}=\frac{\overline{E_{l s}^{\text {post }}}-\overline{E_{l s}^{\text {pre }}}}{\overline{E_{l s}^{\text {pre }}}},
\end{gathered}
$$

where $\overline{E_{l s}^{\text {pre }}}$ is the mean real equivalized expenditure by families of loweducated single mothers on an item in the prereform period (1990-95), and $\overline{E_{l s}^{\text {post }}}$ is the corresponding expenditure in the postreform (1998-2003) period. Under the levels method, $\lambda_{l s}$ estimates the absolute change in mean quarterly expenditure. The percentage method measures the percentage change in mean quarterly expenditure. If no other factors influence family expenditures in the 2 periods, $\lambda_{l s}$ provides welfare reform's estimated effect on spending for this item by the families of low-educated single mothers. However, there may be other factors that affect spending patterns (e.g., economic trends that affect incomes, and therefore expenditure levels, or changes in relative prices).

The DDD methodology controls for time-varying factors that are correlated with welfare reform and may affect expenditure patterns (absolute as well as relative). The methodology is implemented in three steps. In a first step, two sets of computations are made. In the first, item-by-item change in expenditure (postreform minus prereform) is computed for two groups: families headed by single mothers without a high school degree (also referred to as low educated) and families headed by single mothers with at least a bachelor's degree (BA; also referred to as high educated). In the second step, the item-by-item change in expenditure in families headed by high-educated single mothers is subtracted from the item-by-item change in expenditure in families headed by low-educated single mothers. This step essentially controls for factors that have a similar effect on the families of low- and higheducated single mothers. The estimated difference in difference (DD) can be specified as

$$
\lambda_{s}^{2}=\lambda_{l s}-\lambda_{h s},
$$

where $\lambda_{h s}$ is the change in equivalized expenditures on an item by the family of a high-educated single mother after welfare reform. Since 
families of high-educated single mothers are assumed to be unaffected by welfare reform, $\lambda_{h s}$ captures the secular trends correlated with welfare reform. The variable $\lambda_{s}^{2}$ thus estimates whether the trend in expenditure differs for the respective families of low- and high-educated single mothers. If the estimated value of $\lambda_{s}^{2}$ is positive, the relative gap narrowed between the families of low- and high-income single mothers. Equation (2) can be computed using either the level or percentage method described in equation (1).

The identifying assumption in equation (2) is that time-varying factors correlated with welfare reform have the same effect on the target and comparison groups. This may be a rather restrictive assumption since the labor market opportunities for low-educated women differed from the opportunities that high-educated women encountered during the 1990s. To control for these differences, step 2 of the DDD procedure estimates equation (2) for married-couple families, stratified by the mother's education:

$$
\lambda_{m}^{2}=\lambda_{l m}-\lambda_{h m}
$$

Because married parents are at low risk of being on welfare, $\lambda_{m}^{2}$, the second DD captures the difference in the effect of other (than welfare reform) factors on the expenditure patterns of the families of low-educated married couples and those of their high-educated counterparts. Step 3 assumes that the convergence (or divergence) in the spending patterns across groups with different education levels is the same, regardless of mother's marital status. In this final step, the expenditure gap between families of low- and high-educated single mothers is compared with a similar expenditure gap between the families of low- and high-educated married mothers. This provides the DDD estimate, which is the result of equation (3):

$$
\lambda^{3}=\lambda_{s}^{2}-\lambda_{m}^{2}
$$

The DDD estimate in equation (3) can also be obtained in one step by using the following regression on a combined sample of singlemother and married-couple families:

$$
\begin{aligned}
E_{i t}= & \lambda_{0}+\lambda_{p} \text { Policy }_{t}+\lambda_{s} S m_{i t}+\lambda_{e} L e_{i t}+\lambda_{e s}\left(S m_{i t} \times L e_{i t}\right) \\
& +\lambda_{s p}\left(\text { Policy }_{t} \times S m_{i t}\right)+\lambda_{e p}\left(\text { Policy }_{t} \times L e_{i t}\right) \\
& +\lambda_{e s p}\left(\text { Policy }_{j t} \times L e_{i j t} \times S m_{i t}\right)+X_{i t} \Gamma+\delta_{m}+u_{i t}
\end{aligned}
$$

In equation (4), $E_{i t}$, the quarterly equivalized expenditure incurred by family $i$ in period $t$, is a function of Policy, family characteristics $\left(X_{i t}\right)$, and $\delta_{m}$, a vector that represents month-of-interview effects. Variable Policy is coded as one if an observation is taken from the postreform period (it is otherwise zero). Family characteristics include mother's 
age, race and ethnicity, and level of education, as well as whether the family lives in an urban area, the family size, the number of children under age 18, and the number of family members ages 64 or above. The variable $S m_{i t}$ is an indicator of whether the family is headed by a single mother, and $L e_{i t}$ is a dummy variable that indicates whether the mother is low educated. The first-level difference (1st D), DD, and DDD coefficients are given by $\lambda_{p}+\lambda_{e p}+\lambda_{s p}+\lambda_{e s s}, \lambda_{e p}+\lambda_{e s p}$, and $\lambda_{e s p}$, respectively. As in Gregg and associates' (2006) study, the percentage estimates are computed by dividing the difference between pre- and postreform expenditures for a group by the mean expenditure in the prereform period:

$$
\begin{gathered}
1 \text { st } \mathrm{D}=\frac{\lambda_{p}+\lambda_{e p}+\lambda_{s p}+\lambda_{e s p}}{\lambda_{0}+\lambda_{e}+\lambda_{s}+\lambda_{e s}} ; \\
\mathrm{DD}=\frac{\lambda_{p}+\lambda_{e p}+\lambda_{s p}+\lambda_{e s p}}{\lambda_{0}+\lambda_{e}+\lambda_{s}+\lambda_{e s}}-\frac{\lambda_{s p}+\lambda_{p}}{\lambda_{0}+\lambda_{s}} ; \\
\mathrm{DDD}=\frac{\lambda_{p}+\lambda_{e p}+\lambda_{s p}+\lambda_{e s p}}{\lambda_{0}+\lambda_{e}+\lambda_{s}+\lambda_{e s}}-\frac{\lambda_{p}+\lambda_{e p}}{\lambda_{0}+\lambda_{e}}-\frac{\lambda_{s p}+\lambda_{p}}{\lambda_{0}+\lambda_{s}}+\frac{\lambda_{p}}{\lambda_{0}} .
\end{gathered}
$$

In the empirical analysis, base-level expenditures adjust for family characteristics. Huber-White sandwich standard errors are compiled to allow for arbitrary heteroscedasticity in the data. To adjust for potential nonindependence among observations belonging to the same family, standard errors are computed by clustering at the family unit.

The success of this research design critically depends on the choice of comparison groups and the validity of the identifying assumption that convergence (or divergence) in the spending patterns across families in which mothers have different educational levels is the same, irrespective of mothers' marital status. Ideally, comparison groups should be similar to the target group but unaffected by welfare reform. However, it is difficult to find such comparison groups. Although the current comparison groups are much less likely than the target group to have received welfare, their rates of welfare receipt are not zero. In 1994, the year when welfare caseloads peaked, 8 percent of single mothers with at least a BA degree, 9 percent of married mothers without a high school degree, and 0.3 percent of married mothers with at least a BA degree received welfare. Since a small proportion of the comparison groups are affected by welfare reform, the estimated DDD will contain a downward bias.

The target and comparison groups are stratified by the mother's marital status. If welfare reform caused an increase in the probability of marriage among low-educated single mothers, the research strategy 
could suffer from misspecification and sample selection bias. In other words, this could occur if, in the postreform period, members of the target group (single mothers from the prereform period) moved into the comparison group (married mothers). However, previous research suggests that welfare reform does not have any effect on marital status (Schoeni and Blank 2000; Kaushal and Kaestner 2001). A related issue is that welfare reform may affect cohabitation, which may increase family incomes and therefore expenditures. If this is the case, estimates will measure the effect of the increase in cohabitation as well as other effects of welfare reform (e.g., increased employment) on expenditures.

Finally, the DDD methodology may suffer from biased estimates if the identifying assumption, that convergence (or divergence) in the spending patterns across families in which mothers have different educational levels is the same irrespective of the mother's marital status, fails. In this case the direction of the bias is uncertain. This work does not compare the expenditure patterns in married-couple families with those in single-mother families, nor does it compare expenditure patterns of high-income families with those of their low-income counterparts. Rather, it compares the difference in trends in expenditures between low- and high-educated married-couple families (DD) with the difference in trends in expenditures between low- and high-educated singlemother families (DD) to arrive at the estimates (DDD). Thus, the identifying assumption is less restrictive than would be the case if the comparisons were between low-educated and high-educated families or if the comparisons were between single-mother and married-couple families. However, if factors other than welfare reform increased (or narrowed) the gap in expenditures between the families of low- and higheducated married couples more than the gap between those of low- and high-educated single mothers, there would be a bias in the DDD estimate.

There are thus limitations to the comparison-group research design. ${ }^{6}$ At the very least, however, the DDD approach identifies whether any of welfare reform's observed effects on expenditure patterns are group specific and whether the effects are primarily found for the target group (the families of low-educated single mothers). Given the limitations of the research methodology, this article presents multiple sets of findings: the estimated first-difference, DD, and DDD coefficients.

\section{Results}

Major Expenditure Categories: Descriptive Analysis

Figure 1 presents total quarterly equivalized real expenditures for various groups of families headed by single mothers and married parents. The results are stratified by the level of the mothers' education. Ex- 


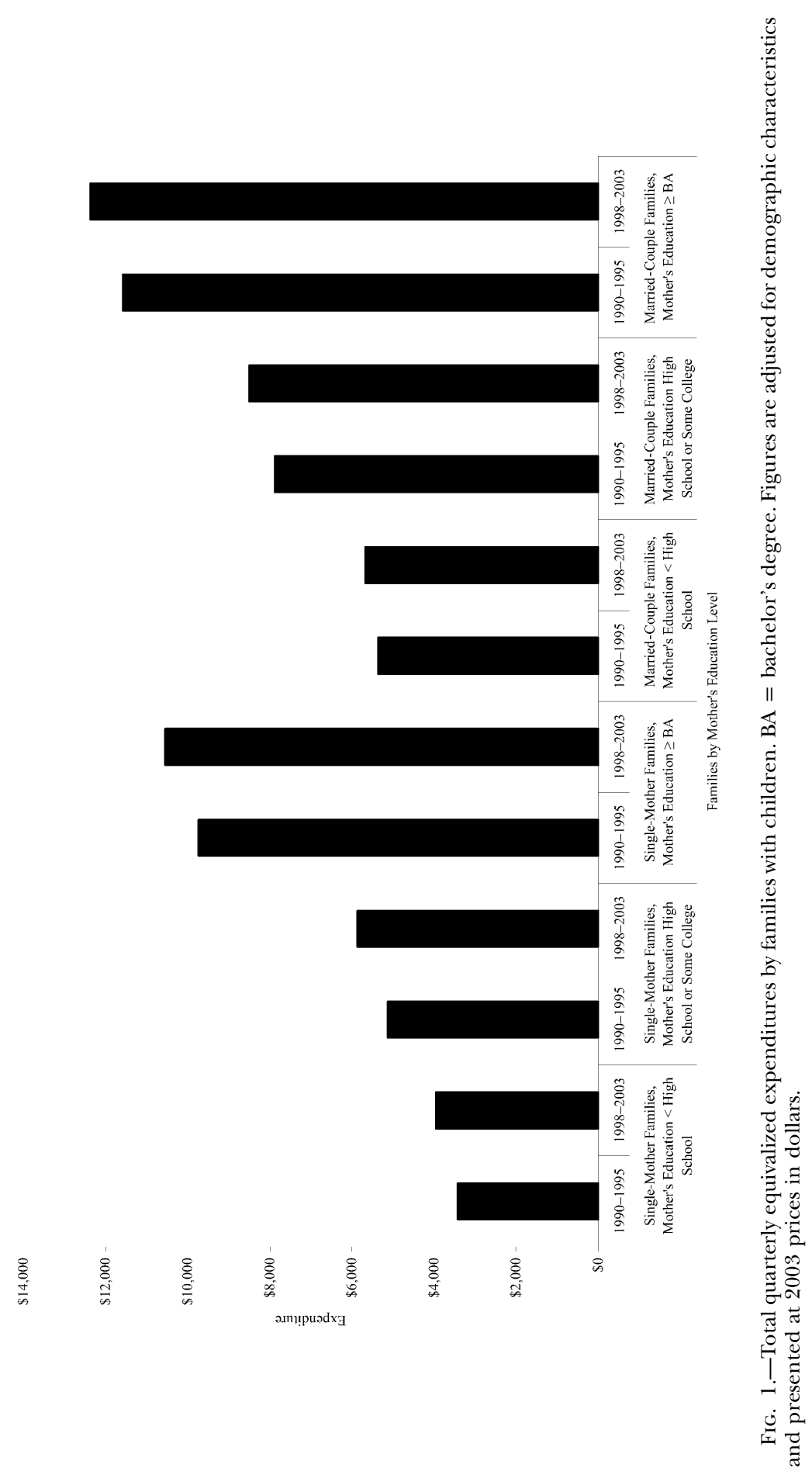


penditures are presented for the target group (families of low-educated single mothers), the comparison groups (the families of high-educated single mothers, of low-educated married couples, and of high-educated married couples). For comparison purposes, the figure presents expenditures of two other groups not in the main analyses. These groups are the families of medium-educated (high school degree or some college) single mothers and those of medium-educated married couples. Expenditure figures are adjusted for mothers' age, race and ethnicity, and education, as well as for whether the family lives in an urban area, family size, number of children under age 18 , number of family members age 65 or above, and month-of-interview effects. The figure suggests that equivalized family expenditures for all six groups increased between prereform (1990-95) and postreform (1998-2003) periods. The increase may reflect the 1990s economic boom. The increase in expenditures seems to be slightly higher for single-mother families than it was for married-couple families, and among single-mother families, the high educated appear to have gained more than the low educated did. However, it is difficult to comment from this figure on proportional changes in family expenditures relative to the base. Multivariate regression models examine this issue.

\section{Major Expenditure Categories: Multivariate Analysis}

Table 1 presents a summary of estimates of the association between welfare reform and major categories of expenditures based on models outlined in equations (1) and (4) for the families of low-educated (without a high school degree) single mothers. Columns 1 and 2 show the adjusted means of real equivalized expenditures per quarter in the 5 years before welfare reform $(1990-95$; col. 1$)$ and the 5 years after the adoption of welfare reform (1998-2003; col. 2). Column 3 shows the difference in levels between the mean expenditures in the prereform period and those in the postreform period (i.e., the difference between col. 2 means and col. 1 means). Column 6 expresses the same differences as percentages. Columns 4 and 5 show the results of the levels analyses that are based on equation (4). In columns 7 and 8 , the same analyses are presented as percentages (using the percentage method). Heteroscedasticity-adjusted standard errors are clustered at the consumer unit and are presented in parentheses.

Estimates in the first (total) row suggest that, between the prereform (1990-95) and the postreform (1998-2003) period, total real equivalized quarterly expenditures in the families of low-educated single mothers increased by a statistically significant $\$ 529$ (or 16 percent). On an annualized basis, this represents an increase of $\$ 2,116$. As shown in figure 1, total equivalized expenditure among the comparison group (families of high-educated single mothers) increased by a higher level 
Table 1

Estimates of Major Quarterly Expenditures in Families Headed by Low-Educated (Education < High School Degree) Single Mothers

\begin{tabular}{|c|c|c|c|c|c|c|c|c|}
\hline & \multicolumn{2}{|c|}{$\begin{array}{l}\text { QUARTERLY MEAN- } \\
\text { ADJUSTED EXPENDI- } \\
\text { TURE (in } 2003 \\
\text { dollars) }\end{array}$} & \multicolumn{3}{|c|}{$\begin{array}{l}\text { LEVEL DifFERENCE IN } \\
\text { MEANS (in } 2003 \text { dollars) }\end{array}$} & \multicolumn{3}{|c|}{$\begin{array}{c}\text { Percentage DifFerence in } \\
\text { MEans }\end{array}$} \\
\hline & $\begin{array}{l}1990-95 \\
(1)\end{array}$ & $\begin{array}{l}1998-2003 \\
(2)\end{array}$ & $\begin{array}{l}\text { 1st D } \\
(3)\end{array}$ & $\begin{array}{l}\text { DD } \\
(4)\end{array}$ & $\begin{array}{c}\text { DDD } \\
(5)\end{array}$ & $\begin{array}{c}\text { 1st D } \\
(6)\end{array}$ & $\begin{array}{l}\text { DD } \\
(7)\end{array}$ & $\begin{array}{c}\text { DDD } \\
(8)\end{array}$ \\
\hline Total & 3,426 & 3,955 & $\begin{array}{l}529 * * * \\
(124)\end{array}$ & $\begin{array}{l}-588 \\
(413)\end{array}$ & $\begin{array}{c}21 \\
(470)\end{array}$ & $\begin{array}{l}15.5^{* * * *} \\
(3.6)\end{array}$ & $\begin{array}{c}2.2 \\
(5.7)\end{array}$ & $\begin{array}{c}4.8 \\
(6.3)\end{array}$ \\
\hline Housing and utility & 1,460 & 1,633 & $\begin{array}{l}173^{* * * *} \\
(52)\end{array}$ & $\begin{array}{l}-423 * * * \\
(175)\end{array}$ & $\begin{array}{l}-186 \\
(199)\end{array}$ & $\begin{array}{l}11.9 * * * \\
(3.6)\end{array}$ & $\begin{array}{c}-6.4 \\
(5.9)\end{array}$ & $\begin{array}{l}-5.8 \\
(6.9)\end{array}$ \\
\hline Food & 947 & 928 & $\begin{array}{c}-19 \\
(26)\end{array}$ & $\begin{array}{c}28 \\
(64)\end{array}$ & $\begin{array}{c}46 \\
(68)\end{array}$ & $\begin{array}{l}-2.0 \\
(2.7)\end{array}$ & $\begin{array}{c}.5 \\
(4.8)\end{array}$ & $\begin{array}{c}3.0 \\
(5.2)\end{array}$ \\
\hline $\begin{array}{l}\text { Alcohol and } \\
\text { tobacco }\end{array}$ & 76 & 83 & $\begin{array}{l}7 \\
(7)\end{array}$ & $\begin{array}{c}6 \\
(12)\end{array}$ & $\begin{array}{c}4 \\
(14)\end{array}$ & $\begin{array}{c}9.0 \\
(9.5)\end{array}$ & $\begin{array}{c}7.5 \\
(15.3)\end{array}$ & $\begin{array}{c}5.9 \\
(16.4)\end{array}$ \\
\hline $\begin{array}{l}\text { Clothing and } \\
\text { footwear }\end{array}$ & 215 & 234 & $\begin{array}{c}19 \\
(14)\end{array}$ & $\begin{array}{l}107 * * \\
(51)\end{array}$ & $\begin{array}{c}22 \\
(53)\end{array}$ & $\begin{array}{c}8.6 \\
(6.3)\end{array}$ & $\begin{array}{l}24.4 * * \\
(10.5)\end{array}$ & $\begin{array}{c}13.6 \\
(11.4)\end{array}$ \\
\hline Transportation & 322 & 581 & $\begin{array}{l}259^{* * * *} \\
(59)\end{array}$ & $\begin{array}{c}97 \\
(153)\end{array}$ & $\begin{array}{c}236 \\
(175)\end{array}$ & $\begin{array}{l}80.4^{* * * *} \\
(18.4)\end{array}$ & $\begin{array}{l}67.8 * * * \\
(20.5)\end{array}$ & $\begin{array}{l}69.2^{* * *} \\
(21.4)\end{array}$ \\
\hline Health & 84 & 83 & $\begin{array}{l}-1 \\
(12)\end{array}$ & $\begin{array}{c}-64^{*} \\
(39)\end{array}$ & $\begin{array}{l}-52 \\
(46)\end{array}$ & $\begin{array}{l}-.5 \\
(14.7)\end{array}$ & $\begin{array}{r}-15.0 \\
(17.5)\end{array}$ & $\begin{array}{c}-12.9 \\
(18.4)\end{array}$ \\
\hline Leisure & 118 & 157 & $\begin{array}{l}39 * * * \\
(10)\end{array}$ & $\begin{array}{l}-45 \\
(44)\end{array}$ & $\begin{array}{l}38 \\
(50)\end{array}$ & $\begin{array}{l}32.9 * * * \\
(8.4)\end{array}$ & $\begin{array}{c}11.8 \\
(13.0)\end{array}$ & $\begin{array}{l}24.7^{*} \\
(14.5)\end{array}$ \\
\hline Personal care & 35 & 37 & $\begin{array}{c}2 \\
(3)\end{array}$ & $\begin{array}{l}-2 \\
(7)\end{array}$ & $\begin{array}{l}-3 \\
(8)\end{array}$ & $\begin{array}{c}6.6 \\
(9.2)\end{array}$ & $\begin{array}{c}5.7 \\
(11.2)\end{array}$ & $\begin{array}{c}6.3 \\
(12.0)\end{array}$ \\
\hline $\begin{array}{l}\text { Education (includ- } \\
\text { ing reading) }\end{array}$ & 23 & 19 & $\begin{array}{l}-4 \\
(4)\end{array}$ & $\begin{array}{c}-78^{*} \\
(46)\end{array}$ & $\begin{array}{l}-21 \\
(50)\end{array}$ & $\begin{array}{r}-17.5 \\
(17.6)\end{array}$ & $\begin{array}{r}-28.6 \\
(39.2)\end{array}$ & $\begin{array}{c}-13.1 \\
(42.2)\end{array}$ \\
\hline Miscellaneous & 146 & 200 & $\begin{array}{l}54 * * * \\
(17)\end{array}$ & $\begin{array}{c}-251 * * \\
(103)\end{array}$ & $\begin{array}{l}-56 \\
(120)\end{array}$ & $\begin{array}{l}37.0 * * * \\
(11.6)\end{array}$ & $\begin{array}{c}1.6 \\
(18.7)\end{array}$ & $\begin{array}{c}7.8 \\
(19.5)\end{array}$ \\
\hline
\end{tabular}

Note.-1st $=$ first level; $\mathrm{D}=$ difference estimates; DD = difference-in-difference estimates; DDD $=$ difference-in-difference-in-difference estimates. Columns 1 and 2 present mean-equivalized expenditures, adjusted for mothers' age, race and ethnicity, education, whether the family lives in an urban area, family size, number of children under age 18 , number of family members age 65 or above, and month-of-interview effects. Expenditures are expressed in January 2003 dollars using the Personal Consumption Expenditure index of the U.S. Bureau of Economic Analysis (n.d.). Heteroscedasticityadjusted standard errors clustered at consumer unit are in parentheses. The comparison group in the DD analysis consists of families headed by high-educated (education $\geq$ bachelor's degree) single mothers. The DDD estimates are derived by subtracting the DD estimates for families of low-educated married couples (with families of high-educated married couples as the comparison group) from the DD estimates for families of low-educated single mothers presented in cols. 4 and 7 . The sample of analysis consists of 3,201 observations of low-educated single mothers, 2,446 observations of higheducated single mothers, 8,217 observations of low-educated married mothers, and 21,143 observations of high-educated married mothers.

$* .05<p \leq .10$.

$* * .01<p \leq .05$

$* * * \quad p \leq .01$.

than the increase experienced by the target group (families of loweducated single mothers). The DD levels estimate for the target group of families (with families of high-educated single mothers as the comparison group) is therefore negative (but not statistically significant). If the percentage method is used, the DD estimate is also not statistically significant.

The DD estimate may be biased if time-varying factors, such as busi- 
ness-cycle effects, influenced incomes (and therefore expenditures) differently in the families of low- and high-educated single mothers. To control for these factors, the DDD coefficients are estimated. These results are not statistically significant, suggesting that welfare reform is not associated with any significant change in total expenditure in families headed by low-educated single mothers.

The pre- to postreform increase in expenditures among the target group is largely due to increases in expenditures in three major categories: housing and utility, transportation, and, to a lesser extent, leisure. ${ }^{7}$ Between the pre- and postreform periods, the target group's quarterly expenditures on housing and utility increased by $\$ 173$ (or 12 percent). The group's expenditures on transportation increased by $\$ 259$ (or 80 percent). Its spending on items of leisure grew by $\$ 39$ (or 33 percent). These changes may be due to several factors, including changes in tastes, relative prices, economy-wide trends, and policy. The DD estimates are calculated to purge the effects of factors that have the same effect on the respective spending patterns of the target and comparison groups. The first difference gain in housing and utility expenditures is completely eliminated in these estimates. In fact, the DD estimate reveals a statistically significant spending decrease of $\$ 423$ (if the DD estimate is calculated with the percentage method, the result is not statistically significant). The increase in expenditures on transportation, however, continues to be large (in percentage terms), even at the DD level. This suggests that the target group spends a statistically significant 68 percent more on transportation in the postreform (1998-2003) period.

In addition, the DD estimates suggest that expenditures on clothing and footwear increased in the families of low-educated single mothers by a statistically significant $\$ 107$ per quarter, expenditures on health fell by $\$ 64$ per quarter, and spending on education fell by $\$ 78$ per quarter. The decreases in the health and education spending are marginally statistically significant $(p<.10)$. Spending in the miscellaneous category falls by $\$ 251$ per quarter. Coefficients estimated using the percentage method reveal statistically significant increases in spending on clothing and footwear as well as on transportation but not on items in the other categories. The point estimates are large and negative for housing and utility, health, and education, but the results are not statistically significant.

The DD estimates do not control for factors that may affect low- and high-educated families differently. The DDD estimates that adjust for these factors suggest that welfare reform increased the target group's expenditures on transportation by 69 percent (the coefficient in levels' terms is not statistically significant). The increase in expenditures on transportation is consistent with predictions that welfare reform's emphasis on work would increase employment among low-educated single 
mothers and, as a result, would also increase such work-related expenditures as transportation. The target group's leisure category expenditures rose by 25 percent, and the coefficient is marginally statistically significant (the coefficient using the level method is not statistically significant). The estimated coefficients for all other categories of expenditures are statistically insignificant. ${ }^{8}$

To summarize, the results presented in table 1 suggest that welfare reform does not have any statistically significant association with total expenditures in families headed by low-educated single mothers. The composition of expenditures changes, however; in the postreform period, families headed by low-educated single mothers spent a significantly larger proportion of their budget on transportation and leisure.

\section{Detailed Expenditure Categories: Descriptive Analysis}

Figure 2 illustrates spending by the four family groups during the prereform (1990-95) period. The figure illustrates expenditures on clothing and footwear, child care and babysitting, and learning and enrichment activities. Results suggest that, in the prereform period, families of loweducated single mothers spent 26 percent of their budget (equivalized total expenditure) on food at home and 3 percent on food away from home. In comparison, the other three groups spent a smaller proportion of their budget on food at home. This finding is expected because the overall size of each of the three groups' budgets is bigger than that of the target group. However, figure 2 suggests that, in contrast to the target group, the comparison groups allocated a higher proportion of their budget for food away from home. The other groups, particularly those headed by more educated mothers, also are found to have invested a much higher proportion of the budget on learning and enrichment than did the target group. In this prereform period, the families of loweducated single mothers spent a relatively small proportion of their budget on clothing and footwear, learning and enrichment, and child care and babysitting, as compared to the other groups. The target group's relatively small budget (compared to those of the comparison groups) suggests that the estimated gap in spending between the target and comparison groups is even larger in absolute (dollar) terms. Regression analyses, as outlined in equations (1) and (4), estimate the effect of welfare reform on these categories.

\section{Detailed Expenditure Categories: Multivariate Analysis}

Table 2 presents a summary of the estimated associations between welfare reform and expenditures on detailed items by the families of low-educated (education < high school degree) single mothers. The regression models have the same controls as the analysis (table 1) on major expenditure categories. 


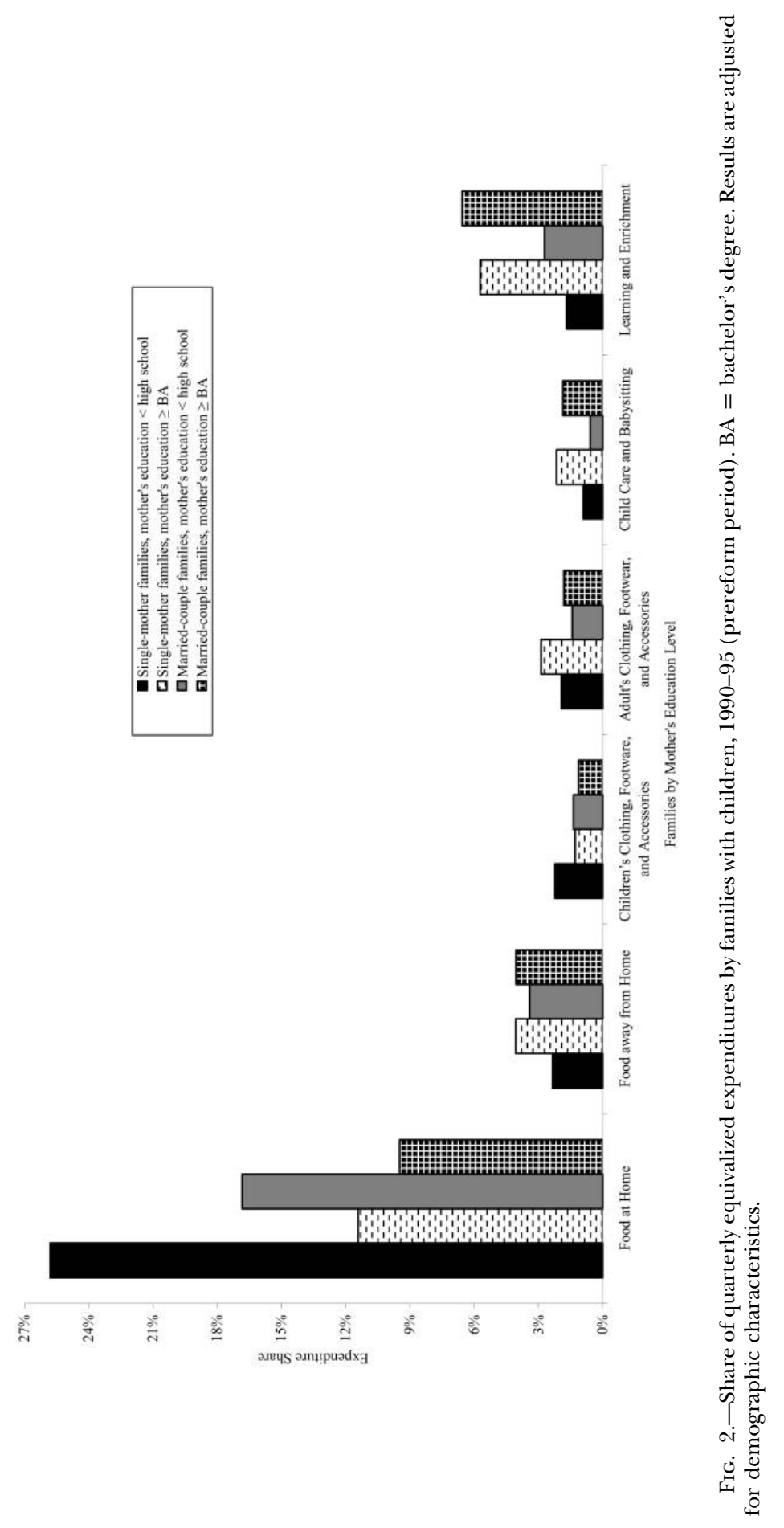




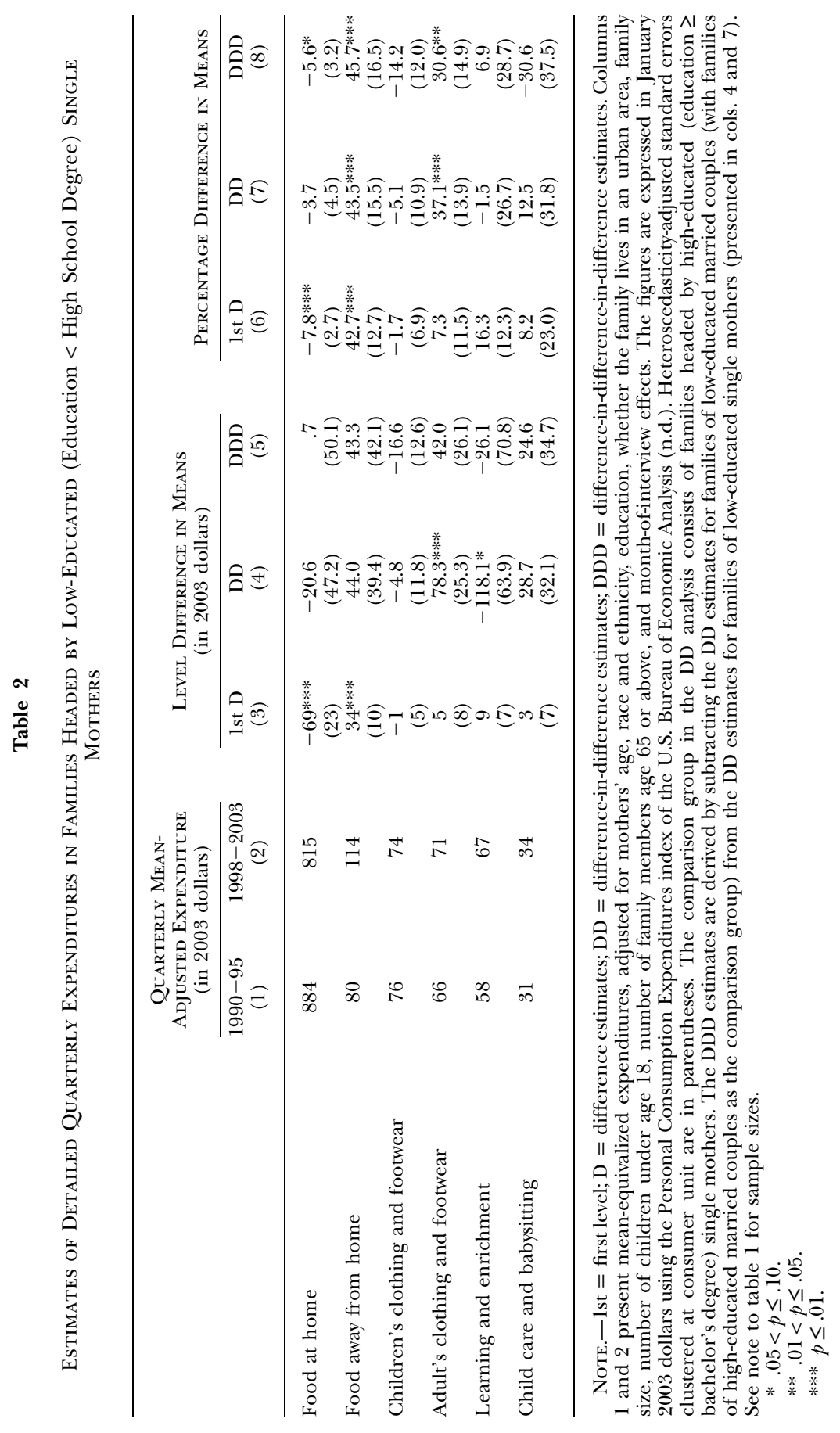


The top two rows in table 2 present mean quarterly expenditures on food at home and food away from home. Results suggest that, between the prereform (1990-95) and postreform (1998-2003) periods, the families of low-educated single mothers decreased equivalized quarterly expenditures on food at home by a statistically significant $\$ 69$ (or 8 percent). They raised expenditures on food away from home by a statistically significant $\$ 34$ (or 43 percent). The DD estimates suggest that, in the postreform period, the families of low-educated single mothers increased expenditures on food away from home by a statistically significant 43.5 percent. The DD estimates may be biased if the two groups' (families of the low- and high-educated single mothers) food expenditures, at home or away from home, are affected differently by the factors contemporaneous with welfare reform. The DDD estimates control for these unobserved factors. The DDD results suggest that welfare reform is associated with a 5.6 percent decline in expenditures on food at home and a 45.7 percent increase in spending on food away from home. The coefficient for spending on food at home is only marginally statistically significant (at $p<.10)$.

The target group's equivalized expenditures on clothing and footwear, both for children and adults, remained almost unchanged from the prereform (1990-95) through the postreform (1998-2003) period. The DD estimate, however, indicates a statistically significant $\$ 78$ (or 37 percent) increase in target group expenditures on adult clothing and footwear. The DD estimates reveal no statistically significant change in target group spending on children's clothing and footwear. The DDD results estimate a statistically significant 30.6 percent increase in target group expenditures on adult clothing and footwear, but results again show no statistically significant change in spending on children's clothing and footwear.

The next estimates examine whether welfare reform is associated with changes in expenditures on learning and enrichment. These include expenditures on books, magazines, and newspapers; tuition, schoolbooks, supplies, and equipment; computers, calculators, and typewriters; toys, games, hobbies, and playground equipment; sports equipment; and other enrichment activities. Although the DD estimate indicates a statistically significant decrease of $\$ 118$ on learning and enrichment, the DDD estimate suggests that there was no statistically significant change.

Finally, the target group's child-care and babysitting expenditures are examined in the last row of table 2 . Welfare reform increased child-care subsidies. If well targeted, these subsidies should offset child-care expenses for low-income families. The CES measure of child care and babysitting, however, does not include state subsidy. Thus, even if the work-oriented policies of welfare reform prompted low-income families to increase use of child care, expenditures on child care, as measured by CESs, may not show a significant increase. It is also possible that low- 
income families increased their reliance on relatives or other informal sources of care in the postreform period. At the same time, higherincome families may benefit from tax credits, for which the lowestincome families would not be eligible. This effect may induce higherincome families to purchase more child care and, thus, may bias estimates such that welfare reform is not found to affect low-income families' child-care expenditures to a statistically significant degree. These considerations may explain statistically insignificant changes in child-care expenditures associated with welfare reform.

To summarize, the preceding analysis suggests that welfare reform is associated with an increase in target group (families of low-educated single mothers) spending on items that may be related to work expenses such as spending on food away from home and adults' clothing and footwear. ${ }^{9}$ There is no corresponding increase in spending on children's clothing and footwear or on learning and enrichment. Finally, the results suggest that there is no statistically significant change in target group spending on child care and babysitting.

\section{Ownership of Consumer Durables}

Figure 3 presents findings on ownership of seven consumer durables in the prereform period and depicts differences across the four demographic groups. Ownership of these items is most limited among the families of low-educated single mothers. The families of low-educated married couples also report that ownership is limited. The families of high-educated married couples consistently report the highest levels of ownership.

A multivariate analysis examines how welfare reform affects ownership of consumer durables. The results are presented in table 3 . As the table suggests, the families of low-educated single mothers increased ownership of microwave ovens in the postreform period. Microwave ovens may reduce time on housework and thus may facilitate work outside the home, but there is no statistically significant change in the target group's ownership of dishwashers or washers and dryers. ${ }^{10}$ The increase in microwave ownership is also seen in the DD estimates, but these estimates could be driven by welfare reform or by such differences between the target group and high-educated single mothers' families as economic prosperity or personal tastes. The DDD estimates, employed to control for unobserved effects correlated with policy, show no statistically significant association between welfare reform and ownership of microwave ovens. These estimates also indicate that welfare reform is not statistically significantly associated with ownership of washers and dryers or dishwashers. Therefore, there is no evidence that welfare reform improves the ability of target group families to own these household appliances. 


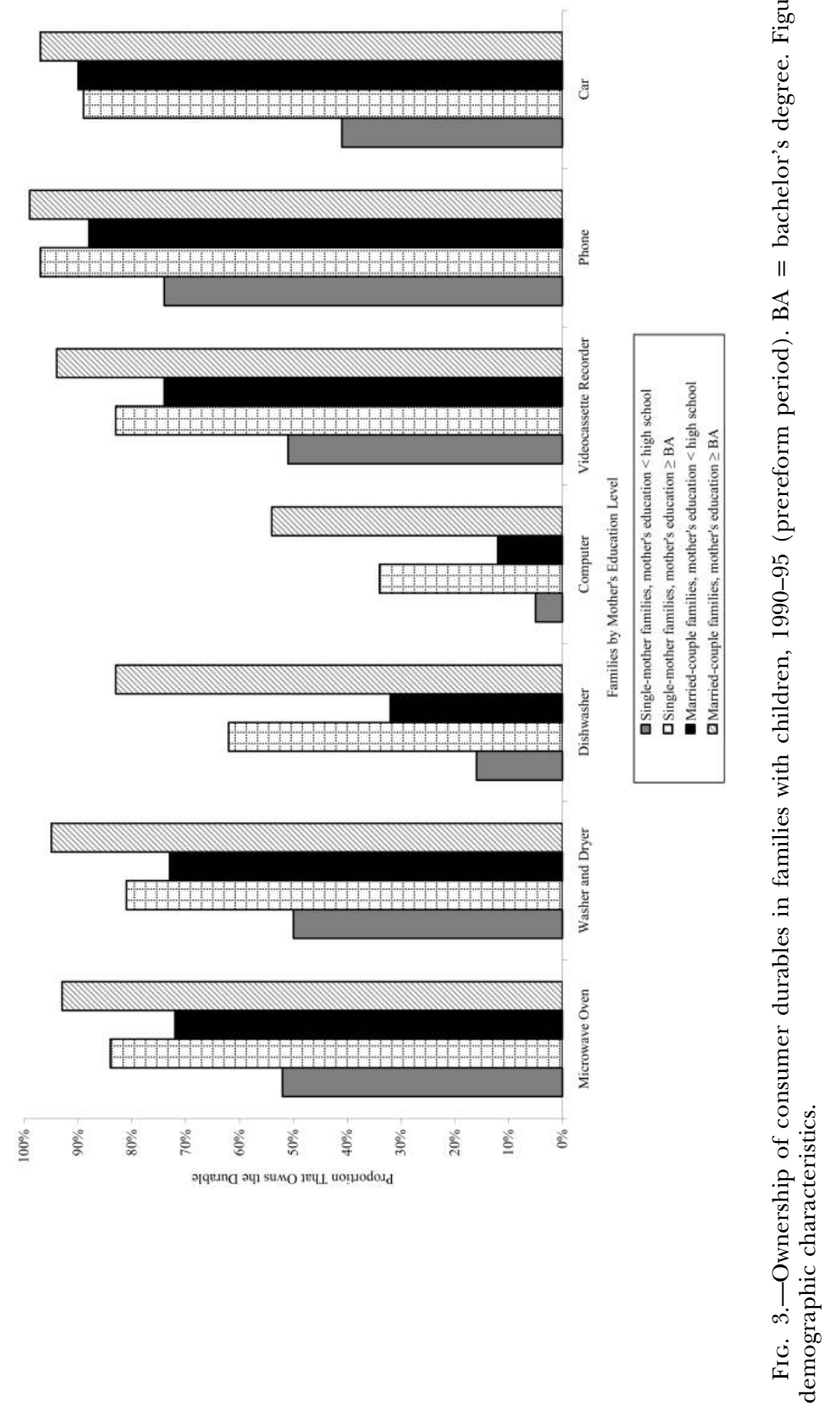


Table 3

Estimates of Ownership of Durables in Families Headed by Low-Educated (Education < High School Degree) Single Mothers

\begin{tabular}{|c|c|c|c|c|c|}
\hline & \multicolumn{2}{|c|}{$\begin{array}{l}\text { Adjusted Probabilitity } \\
\text { OF OWNERShIP }(\%) \\
\end{array}$} & \multicolumn{3}{|c|}{$\begin{array}{c}\text { Percentage Difference in Means } \\
(\% \text { points })\end{array}$} \\
\hline & $\begin{array}{l}1990-95 \\
(1)\end{array}$ & $\begin{array}{l}1998-2003 \\
\quad(2)\end{array}$ & $\begin{array}{l}\text { 1st D } \\
(3)\end{array}$ & $\begin{array}{l}\text { DD } \\
(4)\end{array}$ & $\begin{array}{c}\mathrm{DDD} \\
(5)\end{array}$ \\
\hline Microwave oven & 52 & 77 & $\begin{array}{l}24.8^{* * * *} \\
(2.8)\end{array}$ & $\begin{array}{l}14.4 * * * \\
(4.6)\end{array}$ & $\begin{array}{l}4.0 \\
(4.1)\end{array}$ \\
\hline Washer and dryer & 50 & 51 & $\begin{array}{l}1.0 \\
(3.0)\end{array}$ & $\begin{array}{l}-2.8 \\
(4.1)\end{array}$ & $\begin{array}{l}-1.6 \\
(4.4)\end{array}$ \\
\hline Dishwasher & 16 & 19 & $\begin{array}{c}2.7 \\
(2.3)\end{array}$ & $\begin{array}{c}-5.3 \\
(4.4)\end{array}$ & $\begin{array}{c}-6.3 \\
(4.8)\end{array}$ \\
\hline Computer & 5 & 19 & $\begin{array}{l}13.8 * * * \\
(2.0)\end{array}$ & $\begin{array}{l}-28.5 * * * \\
(4.0)\end{array}$ & $\begin{array}{c}-16.1^{* * * *} \\
(4.4)\end{array}$ \\
\hline VCR & 51 & 71 & $\begin{array}{l}20.4 * * * \\
(2.9)\end{array}$ & $\begin{array}{l}8.8^{* *} \\
(3.9)\end{array}$ & $\begin{array}{l}1.2 \\
(4.2)\end{array}$ \\
\hline Phone & 74 & 88 & $\begin{array}{l}13.4^{* * * *} \\
(2.0)\end{array}$ & $\begin{array}{l}13.2^{* * * *} \\
(2.2)\end{array}$ & $\begin{array}{l}6.4^{* * * *} \\
(2.4)\end{array}$ \\
\hline Car & 41 & 52 & $\begin{array}{l}10.3^{* * * *} \\
(2.7)\end{array}$ & $\begin{array}{l}7.5^{* * * *} \\
(3.6)\end{array}$ & $\begin{array}{l}6.4^{*} \\
(3.8)\end{array}$ \\
\hline
\end{tabular}

NotE. -1 st $=$ first level $; \mathrm{D}=$ difference estimates; $\mathrm{DD}=$ difference-in-difference estimates; DDD = difference-in-difference-in-difference estimates; VCR = videocassette recorder. Columns 1 and 2 present results adjusted for mothers' age, race and ethnicity, education, whether the family lives in an urban area, family size, number of children under age 18 , number of family members age 65 or above, and month-of-interview effects. Heteroscedasticity-adjusted standard errors clustered at consumer unit are in parentheses. The comparison group in the DD analysis consists of families headed by high-educated (education $\geq$ bachelor's degree) single mothers. The DDD estimates are derived by subtracting the DD estimates for families of low-educated married couples (with families of high-educated married couples as the comparison group) from the DD estimates for families of low-educated single mothers (presented in col. 4). The sample of analysis consists of 2,941 observations of unmarried low-educated mothers, 2,021 observations of unmarried high-educated mothers, 8,218 observations of married low-educated mothers, and 20,888 observations of high-educated married mothers.

$$
\begin{aligned}
& * .05<p \leq .10 . \\
& * * .01<p \leq .05 . \\
& * * * \quad p \leq .01 .
\end{aligned}
$$

Results suggest that, in the postreform period, ownership of computers and VCRs, items that may be used for learning and enrichment, increased by 14 and 20 percentage points, respectively, in families headed by low-educated single mothers. The ownership of VCRs and computers also increased among families headed by high-educated single mothers. The DD estimates indicate that VCR ownership among the target group of families (those headed by low-educated single mothers) rose by 9 percentage points. The same estimates suggest that computer ownership decreased by 29 percentage points in the target group of families. The DDD estimates suggest that welfare reform is associated with a statistically significant 16.1-percentage-point decline in computer 
ownership among target group families, but DDD estimates reveal no statistically significant change in VCR ownership.

The first difference estimates for phone and car ownership show that in the postreform period (1998-2003), phone ownership (i.e., the proportion of families that spent any amount on phone services) among target group families increased by 13.4 percentage points; car ownership in this group rose by 10.3 percentage points. Statistically significant DD estimates show that phone and car ownership remained stagnant or increased modestly among families headed by high-educated single mothers. Finally, the DDD estimates suggest that welfare reform is associated with a statistically significant 6-percentage-point increase in ownership of cars and of phones among target group families. The DDD estimate for car ownership is only marginally statistically significant.

The analysis thus suggests that the families of low-educated single mothers increased their ownership of several consumer durables in the postreform period. There also appears to be an increase in ownership of these items among other groups that were unaffected by welfare reform. After adjusting for secular trends in ownership of durables, estimates suggest that welfare reform is associated with increased ownership of phones and cars among families headed by low-educated single mothers, but ownership of computers declines among these families.

\section{Conclusion}

This article investigates the association between welfare reform, broadly defined to include an array of social policy changes in the 1990s, and the expenditure patterns of families headed by low-educated single mothers. The CESs for 1990-95 and 1998-2003 are used, and a DDD research design is employed to control for factors that are correlated with welfare reform and that may affect the material circumstances of single-mother families. Results suggest that welfare reform does not have any statistically significant association with total expenditures in families headed by low-educated single mothers. The composition of household expenditures changed, however; in the postreform period (1998-2003), families headed by low-educated single mothers spent a significantly larger proportion of their budget on work-related expenses (insignificant declines are observed in spending on housing and utility, health, and education). Results indicate that welfare reform is associated with increases in target group (families headed by low-educated single mothers) spending on transportation and food away from home, as well as on adult clothing and footwear. However, welfare reform is not associated with any statistically significant increase in spending on children's clothing and footwear. If anything, the negative (although statistically insignificant) estimates for children's clothing and footwear suggest that 
expenditures on these items may have declined in the postreform period.

The analysis finds no statistically significant increase in expenditures on learning and enrichment. The results suggest that inequality persists in expenditures on learning and enrichment; social policy in the 1990s did not reduce the gap between low- and high-income families. Finally, results show that there was no significant change in spending on child care among families headed by low-educated single mothers. This result may reflect the expansion of child-care subsidies in the 1990s; if well targeted to the neediest families, such subsidies may offset family childcare costs. It is also possible that moderate- and high-income families increased their spending on child care in response to child-care tax credits. This may bias the results by obscuring increases in child-care expenditures among low-income families that cannot avail themselves of these credits. It is also possible that low-income families increased their reliance on relatives or other informal sources of child care.

Estimates further suggest that welfare reform is associated with increased ownership of phones and cars among families of low-educated single mothers. The same families report a decline in ownership of computers.

Many of the statistically significant changes in expenditures are small in magnitude (and many others are not statistically significant). Thus, conclusions about the changes in expenditures of low-income singlemother families remain somewhat tentative. Nevertheless, the results are quite consistent in suggesting that patterns of expenditures changed among families affected by welfare reform and that change entailed increases in expenditures on work-related items but not on learning and enrichment. These results reflect welfare reform's emphasis on employment but leave open the question of child well-being. 


\section{Appendix}

Table A1

Major Expenditure Categories

Category Description of Expenditure

Housing and utility Housing expenditures include the following four categories: a) Shelter costs, including those for owned dwellings and owned vacation homes (mortgage interest, property taxes, maintenance, repairs, insurance, parking fees, contractors' labor and material costs, and management fees), rent, lodging away from home on trips, and housing for someone at school

b) Utility costs, including those for natural gas, electricity, fuel oil and other fuels, telephone services, water, and other public services

c) Household operations, including domestic services (babysitting and child care included) and other household expenses such as the cost of materials purchased for termite and pest control; moving, storage, and freight express; repair of furniture and household appliances; and rental and installation of dishwasher, disposal, and range hood

d) House furnishings and equipment, including household textiles, furniture, floor coverings, built-in dishwasher, garbage disposal, purchase and installation of refrigerator or home freezer, clothes washer or dryer, cooking stove, range or oven, microwave, portable dishwasher, window air conditioner, electric floor-cleaning equipment, sewing machines, dinnerware, flatware, glassware, nonelectric cookware, small electrical kitchen appliances, portable heating and cooling equipment, and other miscellaneous household equipment

Food

Food that is prepared at home and away from home (including meals provided as pay and those not as pay)

Alcohol and tobacco Alcoholic beverages, cigarettes, cigars, pipe tobacco, and other tobacco products

Clothing, footwear, Sum of clothing and footwear for men, women, boys, and girls and accessories

Transportation and other apparel products and services, including sewing materials for making clothes, watches, jewelry, shoe repair and other shoe services, apparel laundry and dry cleaning, alteration, repair, and tailoring of apparel and accessories, clothing rental, watch and jewelry repair, and clothing storage

Cars, trucks (new and used), and other vehicles; gasoline and motor oil; vehicle finance charges, maintenance, and repairs; vehicle insurance, vehicle rental, leases, licenses, and other charges; and public transportation, both local and on trips

Health

Health insurance, medical services, prescription drugs, and medical supplies Feisure $\quad \begin{aligned} & \text { Fees for and admissions to entertainment activities; televisions, } \\ & \text { radios, and sound equipment; pets, toys, and playground }\end{aligned}$ equipment; and other entertainment

Personal care

Wigs, hairpieces, or toupees; electric personal-care appliances; and personal-care services for males and females, including haircuts

Education (including Tuition, schoolbooks, supplies, and equipment for college, elereading) mentary school, high school, day care, nursery school, and other schools; rentals of books, equipment, and other schoolrelated expenses; newspapers and magazines (subscriptions and nonsubscriptions), books (purchased but not through book clubs), and encyclopedias and other sets of reference books 
Table A1 (Continued)

\begin{tabular}{|c|c|}
\hline Category & Description of Expenditure \\
\hline Miscellaneous & $\begin{array}{l}\text { Membership fees for credit card memberships and shopping } \\
\text { clubs; lotteries and pari-mutuel losses; legal fees (excluding } \\
\text { real estate closing costs); funeral, burial, or cremation ex- } \\
\text { penses; accounting fees; interest on line-of-credit home equity } \\
\text { loan (properties other than owned homes); occupational ex- } \\
\text { penses; }{ }^{*} \text { cash contributions, including alimony and child sup- } \\
\text { port expenditures and support for college students; gifts to } \\
\text { non-consumer-unit members of stocks, bonds, and mutual } \\
\text { funds; cash contributions to charities, churches or religious } \\
\text { organizations, educational institutions, political organizations, } \\
\text { and other organizations; other cash gifts; and life and other } \\
\text { personal insurance, retirement, pensions, and Social Security } \\
\text { contributions }\end{array}$ \\
\hline Total & Total of above \\
\hline
\end{tabular}

* The Consumer Expenditure Surveys codebook does not provide any detail on how occupational expenses are defined.

Table A2

Detailed Expenditures for Children and Adults

\begin{tabular}{|c|c|}
\hline Category & Description of Expenditure \\
\hline Children's clothing and footwear & Children's clothing, footwear, and accessories \\
\hline Adult's clothing and footwear & Adult's clothing, footwear, and accessories \\
\hline \multicolumn{2}{|l|}{ Learning and enrichment: } \\
\hline $\begin{array}{l}\text { a) Books, magazines, and } \\
\text { newspapers }\end{array}$ & $\begin{array}{l}\text { Books (purchased through book clubs or not), } \\
\text { newspapers, and magazines (purchased through } \\
\text { subscriptions or not) }\end{array}$ \\
\hline $\begin{array}{l}\text { b) Tuition, schoolbooks, sup- } \\
\text { plies, and equipment }\end{array}$ & $\begin{array}{l}\text { Tuition for college, elementary school, high school, } \\
\text { and schools other than day-care centers and nurs- } \\
\text { ery schools; schoolbooks, supplies, and equipment } \\
\text { for college, elementary school, high school, day- } \\
\text { care centers, nursery schools, and other schools; } \\
\text { encyclopedias and other sets of reference books; } \\
\text { rentals of books and equipment; and other } \\
\text { school-related expenses }\end{array}$ \\
\hline $\begin{array}{l}\text { c) Computers, calculators, and } \\
\text { typewriters }\end{array}$ & $\begin{array}{l}\text { Computers, computer systems, and related hard- } \\
\text { ware; computer software and accessories; repair } \\
\text { of computers, computer systems, and related } \\
\text { equipment for nonbusiness use; computer infor- } \\
\text { mation services; calculators; typewriters; and other } \\
\text { office machines for nonbusiness use }\end{array}$ \\
\hline $\begin{array}{c}\text { d) Toys, games, hobbies, and } \\
\text { playground equipment }\end{array}$ & $\begin{array}{l}\text { TV computer games and computer game software, } \\
\text { toys, games, hobbies, tricycles, battery-powered } \\
\text { riders, and playground equipment }\end{array}$ \\
\hline e) Sports equipment & $\begin{array}{l}\text { Ping-Pong table, pool tables, other similar recrea- } \\
\text { tion room items, general sports equipment, and } \\
\text { health and exercise equipment; bicycles; and } \\
\text { camping, hunting and fishing, winter sports, } \\
\text { water sports, and other sports equipment }\end{array}$ \\
\hline
\end{tabular}


Table A2 (Continued)

\begin{tabular}{|c|c|}
\hline Category & Description of Expenditure \\
\hline f) Enrichment activities & $\begin{array}{l}\text { Musical instruments, supplies, and accessories; mem- } \\
\text { bership fees for country clubs, health clubs, swim- } \\
\text { ming pools, tennis clubs, social or other recrea- } \\
\text { tional organizations, and civic, service, or fraternal } \\
\text { organizations; fees for participant sports, such as } \\
\text { golf, tennis, and bowling; management fees for } \\
\text { recreational facilities, such as tennis courts and } \\
\text { swimming poools in condos and co-ops; admission } \\
\text { fees for entertainment activities, including movie, } \\
\text { theater, concert, opera, or other musical series } \\
\text { (single admissions and season tickets); admission } \\
\text { fees to sporting events (single admissions and sea- } \\
\text { son tickets); fees for recreational lessons or other } \\
\text { instructions; rental and repair of musical instru- } \\
\text { ments, supplies, and accessories; and rental and } \\
\text { repair of sports, recreation, and exercise equip- } \\
\text { ment }\end{array}$ \\
\hline Child care and babysitting & $\begin{array}{l}\text { Babysitting or other child care, whether in one's } \\
\text { own home or someone else's home, and tuition } \\
\text { and other expenses (other than schoolbooks, sup- } \\
\text { plies, and equipment) for day care and nursery } \\
\text { schools }\end{array}$ \\
\hline
\end{tabular}

NотE.-Categories $a$ and $b$ of learning and enrichment expenditures are the same as the category education (including reading) in table Al, with one exception. In table Al, tuition on day care and nursery schools is included in education. Here, these items are excluded from learning and enrichment and included in child care and babysitting.

\section{References}

Battistin, Erich. 2003. "Errors in Survey Reports of Consumption Expenditures." Working paper no. WP03107. Institute for Fiscal Studies, London.

$\rightarrow$ Bitler, Marianne P., Jonah B. Gelbach, and Hilary W. Hoynes. 2005. "Welfare Reform and Health." Journal of Human Resources 40 (2): 309-34.

$\rightarrow$ Blank, Rebecca M. 2000. "Distinguished Lecture on Economics in Government: Fighting Poverty; Lessons from Recent U.S. History." Journal of Economic Perspectives 14 (2): 3-19.

$\rightarrow-$. 2002. "Evaluating Welfare Reform in the United States." Journal of Economic Literature 40 (4): 1105-66.

$\rightarrow$ Caban, Alberto J., David J. Lee, Lora E. Fleming, Orlando Gómez-Marín, William LeBlanc, and Terry Pitman. 2005. "Obesity in US Workers: The National Health Interview Survey, 1986 to 2002." American Journal of Public Health 95 (9): 1614-22.

Cancian, Maria, Robert Haveman, Thomas Kaplan, Daniel R. Meyer, and Barbara Wolfe. 1999. "Work, Earnings, and Well-Being after Welfare: What Do We Know?" 161-86 in Economic Conditions and Welfare Reform, edited by Sheldon H. Danziger. Kalamazoo, MI: W. E. Upjohn Institute for Employment Research.

Clinton, William J. 1992. "In Their Own Words: Transcript of Speech by Clinton Accepting Democratic Nomination." New York Times, July 17, late edition, A14.

Council of Economic Advisors. 1999. The Effects of Welfare Policy and the Economic Expansion on Welfare Caseloads: An Update. Technical report. Washington, DC: Executive Office of the President of the United States, Council of Economic Advisors.

Duncan, Greg J., and P. Lindsay Chase-Lansdale, eds. 2004. For Better and for Worse: Welfare Reform and the Well-Being of Children and Families. New York: Russell Sage.

Figlio, David N., and James P. Ziliak. 1999. "Welfare Reform, the Business Cycle, and the 
Decline in AFDC Caseloads." 17-48 in Economic Conditions and Welfare Reform, edited by Sheldon H. Danziger. Kalamazoo, MI: W. E. Upjohn Institute for Employment Research.

$\rightarrow$ Gregg, Paul, Jane Waldfogel, and Elizabeth Washbrook. 2006. "Family Expenditures Postwelfare Reform in the UK: Are Low-Income Families Starting to Catch Up?" Labour Economics 13 (6): 721-46.

Grogger, Jeff, Lynn A. Karoly, and Jacob A. Klerman. 2002. "Consequences of Welfare Reform: A Research Synthesis.” Report no. DRU-2676-DHHS to the U.S. Department of Health and Human Services, Administration for Children and Families. Rand Corporation, Santa Monica, CA.

Haskins, Ron. 2001. "Effects of Welfare Reform on Family Income and Poverty." 103-36 in The New World of Welfare, edited by Rebecca M. Blank and Ron Haskins. Washington, DC: Brookings Institution.

$\rightarrow$ Kane, Thomas J. 1987. "Giving Back Control: Long-Term Poverty and Motivation.” Social Service Review 61 (3): 405-19.

$\rightarrow$ Kaushal, Neeraj, and Robert Kaestner. 2001. "From Welfare to Work: Has Welfare Reform Worked?” Journal of Policy Analysis and Management 20 (4): 699-719.

$\rightarrow$. 2005. "Welfare Reform and Health Insurance of Immigrants." Health Services Research 40 (3): 697-722.

Meyer, Bruce D., and James X. Sullivan. 2003. "Measuring the Well-Being of the Poor Using Income and Consumption.” Journal of Human Resources 38 (suppl.): 1180-1220.

$\rightarrow$. 2004. "The Effects of Welfare and Tax Reform: The Material Well-Being of Single Mothers in the 1980s and 1990s." Journal of Public Economics 88 (7): 1387-1420.

- 2005. "The Well-Being of Single-Mother Families after Welfare Reform." Welfare Reform and Beyond Policy Brief no. 33. Brookings Institution, Washington, DC.

. 2006. "Consumption, Income, and Material Well-Being after Welfare Reform." Working paper no. 11976. National Bureau of Economic Research, Cambridge, MA.

OECD (Organization for Economic Cooperation and Development). n.d. "What Are Equivalence Scales?” http://www.oecd.org/dataoecd/61/52/35411111.pdf (accessed May 24, 2007).

Parrott, Sharon, and Arloc Sherman. 2006. "TANF at 10: Program Results Are More Mixed than Often Understood." Report, August 16. Center on Budget and Policy Priorities, Washington, DC. http://www.cbpp.org/8-17-06tanf.htm.

Primus, Wendell, Lynette Rawlings, Kathy Larin, and Kathryn Porter. 1999. "The Initial Impacts of Welfare Reform on the Incomes of Single-Mother Families.” Report, August. Center on Budget and Policy Priorities, Washington, DC.

Rector, Robert E. 2004. "Understanding Poverty and Economic Inequality in the United States." Backgrounder Report no. 1796. Heritage Foundation, Washington, DC.

Schoeni, Robert F., and Rebecca M. Blank. 2000. "What Has Welfare Reform Accomplished? Impacts on Welfare Participation, Employment, Income, Poverty, and Family Structure." Working paper no. 7627. National Bureau of Economic Research, Cambridge, MA.

U.S. Bureau of Economic Analysis. n.d. "Table 2.8.4: Price Indexes for Personal Consumption Expenditures by Major Type of Product, Monthly." National Income and Product Accounts Table. http://www.bea.gov/national/nipaweb/TableView.asp ?SelectedTable $=80 \&$ FirstYear $=2007 \&$ LastYear $=2007 \&$ Freq $=$ Month $($ accessed May 24, 2007).

U.S. Census Bureau. n.d. "Detailed Poverty Tabulations from the CPS." http://www.census .gov/hhes/www/poverty/detailedpovtabs.html (accessed May 24, 2007).

U.S. Department of Labor, Bureau of Labor Statistics. 2005. "2003 Consumer Expenditure Interview Survey: Public Use Microdata Documentation.” http://www.bls.gov/cex/ csxintvw.pdf.

U.S. House of Representatives, Committee on Ways and Means. 2006. Testimony of June O'Neill. Hearing to Review Outcomes of 1996 Welfare Reforms. 109th Cong., 2nd sess., July 19.

Waldfogel, Jane. 2006. What Children Need. Cambridge, MA: Harvard University Press.

Winship, Scott, and Christopher Jencks. 2002. "Changes in Food Security after Welfare Reform: Can We Identify a Policy Effect?" Working paper no. 286. Northwestern University/University of Chicago, Joint Center for Poverty Research, Chicago.

$\rightarrow$ Ziliak, James P., David N. Figlio, Elizabeth E. Davis, and Laura S. Connolly. 2000. "Ac- 
counting for the Decline in AFDC Caseloads: Welfare Reform or the Economy?” Journal of Human Resources 35 (3): 570-86.

\section{Notes}

The authors are grateful to Liz Washbrook and Geng Li for helpful advice. Send correspondence to Neeraj Kaushal, School of Social Work, Columbia University, 1255 Amsterdam Avenue, New York, NY 10027.

1. Meyer and Sullivan (2006) study trends in shares of expenditures on major items. However, they do not investigate whether these trends are caused by welfare reform or other time-varying contemporaneous factors. They also do not look at the specific expenditure categories examined here.

2. The sample size was increased in 1999. In any single quarter between 1990 and 1998, the IS consisted of about 5,000 units.

3. It is possible that single mothers who started working due to welfare reform may drop out of CESs or answer questions with less care because their work schedules after welfare reform will restrict time for such activities. There is no way to determine whether respondents took less care in answering CESs after welfare reform. According to CES documentation, from 1990 to 2004, there is a steady decline in the response rate. A similar trend is found in response rates in all national surveys during this period (Caban et al. 2005). There is no indication that this trend is more pronounced for the target group than for the comparison groups.

4. Note that this residency requirement was one of the conditions for teenage mothers to stay on welfare (110 Stat. 2136 [1996]). The analysis reported here is repeated after excluding teenage mothers. The estimated coefficients (not shown but available on request) are similar to those reported.

5. Certain items in detailed categories overlap with those in major expenditure categories.

6. As a robustness check, the analysis is repeated, and high-educated groups are defined as those with some college or higher education. The estimated coefficients (not shown but available on request) are similar to those reported.

7. There was also a statistically significant 37 percent increase in expenditures in the miscellaneous category.

8. Some of the statistically insignificant DDD results are large but imprecisely estimated due to large standard errors. For example, welfare reform was associated with a 6 percent decline in target group expenditures on housing and utility, as well as with a 13 percent decline in target group expenditures on health and on education.

9. If the low-educated group is redefined as those with a high school degree or less, analyses (not shown but available on request) suggest that the estimated effects are smaller in magnitude for this group. This is expected, as single mothers with a high school degree are less likely to be affected by welfare reform because they have a lower risk of being on welfare than do their counterparts without the degree.

10. The data in CESs treat washer and dryer as a single durable. 